\title{
Socio-economic status and fertility in an urban context at the end of the nineteenth century: A linked records study from Tartu, Estonia
}

\author{
Mark Gortfelder (corresponding author) ${ }^{1}$, Hannaliis Jaadla ${ }^{2,1}$ and Martin Klesment ${ }^{1}$ \\ $\left({ }^{1}\right.$ Estonian Institute for Population Studies, Tallinn University; \\ ${ }^{2}$ Cambridge Group for the History of Population and Social Structure, Department of \\ Geography, University of Cambridge)
}

\begin{abstract}
The topic of socio-economic fertility differences and its causes during the demographic transition has received a significant amount of attention in historical demography. With few exceptions, however, the previous studies have dealt with Western Europe. This paper increases the geographic range of the literature and investigates the influence of socioeconomic status on marital fertility in an urban population of Tartu, a mid-sized university town in Estonia. Unlike previous studies, we perform both a cross-sectional analysis - using census data to analyse net marital fertility - and event history analysis - using linked-records sample to analyse the probability of next birth after the census. We measure socio-economic status based on the husband's occupation, but also include information on the level of her education, employment and migration status. In line with the literature, our results confirm that women belonging to the highest social group to have considerably lower marital fertility in the early phase of transition. However, there is no linear social gradient in fertility in Tartu. Instead, we find women married to professionals and skilled workers to have higher fertility, whereas low fertility is exhibited also by women married to men working in the low-wage service sector. We fail to find any support that the educational level of the woman was differentiating fertility in the late nineteenth century Tartu. We relate these patterns in fertility to both adjustment to structural forces as well as innovation and diffusion of new demographic behaviour experienced by the local urban population during the fertility transition.
\end{abstract}


Keywords: socio-economic status, fertility transition, historical demography, child-woman ratios, discrete-time event history

\section{Introduction}

Early theorists of the demographic transition thought that the rapidly changing economic structure was responsible for the historic fertility decline experienced in the West. In their opinion, the reduction in fertility first started among social groups who were the most affected by, as well as the most actively involved in, the economic transformation (Davis, 1945; Notestein, 1945). Empirical research, however, has cast doubt on this view. The Princeton project, that set out to prove the transition theory, failed in this regard, highlighting instead the importance of behavioural innovations and changes in norms in close linguistic and cultural communities (Coale \& Watkins, 1986). Szreter's (1996) comprehensive study of fertility in Britain also downplayed the importance of individuals' own social class as a predictor of differences in fertility. He favoured instead an idea of social networks of people with shared norms and values and reinforced by local institutions defined as 'communication communities'. This 'revisionist' interpretation, however, did not achieve consensus. The Princeton project has been criticised for the high level of aggregation of its data, as well as the indices and methods employed (Brown \& Guinnane, 2002, 2007; Guinnane, Okun, \& Trussell, 1994). The data and research Szreter used for his book have been subjected to reanalysis and an opposing interpretation (Barnes \& Guinnane, 2012). The debate that ensued (Barnes \& Guinnane, 2017; Szreter, 2015) demonstrates the lasting significance and complexity of the question.

The problems regarding aggregated data are one of the reasons researchers have begun using micro-level datasets. A host of studies have analysed the role of socio-economic status 
on fertility outcomes during the course of the demographic transition using both small- and large-scale individual-level data. One set of studies has exploited census micro-data from the nineteenth and early twentieth centuries that are available for some European and North American countries (Dribe, Hacker, \& Scalone, 2014; Dribe \& Scalone, 2014; Hacker, 2016; Gruber \& Scholz, 2018; Klüsener, Dribe, \& Scalone, 2019; Jaadla et al., in press). A second strand has employed local register data and event history methods (Bengtsson \& Dribe, 2014; Breschi, Esposito, Mazzoni, \& Pozzi, 2014; Dribe et al., 2017; Molitoris \& Dribe, 2016; Tsuya, Wang, Alter \& Lee, 2010; Van Bavel, 2004; Vézina, Gauvreau, \& Gagnon, 2014). A common feature of these studies is the emergence of significant differences in fertility between social groups during the transition. As expected, the elite and the middle classes were the first in every context to start to limit their fertility, and others followed in time. However, there is some variation across contexts regarding the precise pattern of fertility, as well as the extent of group differences.

These studies have pertained to populations in Western Europe and North America, with only a few exceptions, such as the work by Tsuya and colleagues (2010). One of the main reasons for the lack of research in other regions has been the much slower development of individual-level data. This has also been true of Eastern Europe, where the underdevelopment of historical demographic research has a longer history (Wetherell \& Plakans, 1997). To the best of our knowledge, there has been only one individual-level study, which was based on data from a village in Western Hungary (Pakot \& Öri, 2016), regarding socio-economic differences in fertility during the demographic transition. A descriptive analysis has also been undertaken on Poznan in Poland (Liczbińska, Syska, KoziarskaKasperczyk \& Kledzik, 2018). In addition to the lack of geographic breadth, there is also a discrepancy in the literature between urban and rural populations, since most local case 
studies have used data from rural areas (Molitoris \& Dribe, 2016), although urban areas were more dynamic and diverse at the time.

This study contributes to the existing literature in three ways: first, by extending the evidence regarding historical fertility differentials by social status beyond Western Europe and North America; second, by studying fertility in an urban area, whereas most case studies have dealt with rural settings; and third, by utilising different data sources and methods. We use census data for a cross-sectional approach (own-child method and linear regression), and linked census and register data for an event history approach. Since Tartu was a town with considerable economic and cultural diversity at that time, it provides a good setting for studying socio-economic differences in fertility during the demographic transition.

\section{Innovation and adjustment}

Explanations of fertility decline often distinguish between aspects of 'innovation' and 'adjustment' that need to occur before new reproductive habits are adopted (Carlsson, 1966). The innovation perspective attributes falling fertility to the spread of new methods and knowledge ('technological innovation'), as well as attitudes and norms permissive of family limitation ('moral innovation') (Cleland \& Wilson, 1987). The proponents of this view frequently cite evidence that in pre- or early-transitional societies, knowledge of even the most basic methods of contraception was not widespread, and the concept of family limitation provoked bewilderment or outrage (Cleland, 2001). They also note paradoxes in the relative timing of fertility decline between countries and regions that cannot be explained by economic changes.

The adjustment perspective conceptualises fertility decline as a response to a transformation in the economic and social environment. This is related to the supply-anddemand view, which is based on the changing costs and benefits of having children (Easterlin 
and Crimmins, 1985), as well as to theories regarding the quantity and quality of offspring (Becker, 1991). The main evidence for the adjustment argument comes from the changes in economic organisation in the nineteenth century, during which the introduction of restrictions on children's participation in the labour force, the enforcement of school attendance, and women's entry into the labour market combined to increase the relative costs of having large families. Furthermore, an important variable that disturbed the existing pre-transitional demographic equilibrium was the decline of childhood mortality, since it preceded fertility decline and therefore increased the supply of children (Reher, 1999; Reher, Sandström, SanzGimeno, \& van Poppel, 2017). This is especially important, because studies have shown that with the start of the demographic transition socio-economic differences in infant and child mortality became more pronounced (Breschi, Fornasin, Manfredini, Mazzoni, \& Pozzi, 2011; Edvinsson, Brändström, Rogers, \& Broström, 2005; Haines, 1995). However, these differences in mortality were strongly associated with the local environment and were often magnified in urban or heavily industrialised areas (Reid, 1997). Therefore, we could expect socio-economic differences in fertility to be more pronounced in those areas.

Those who adhere to the two explanations share the understanding that adjustment and innovation processes are more complimentary than explicitly competing explanations (Casterline, 2001). Both sets of researchers also generally agree that analysis of the extent of socio-economic variations in fertility, and how these are transformed during the process of fertility decline, is fundamental to any understanding of the nature of fertility transition. It is important to note that both adjustment and innovation processes could produce the socioeconomic patterns that individual-level studies have shown. In accord with the adjustment view, it is thought that higher social groups, as well as upwardly mobile people (Van Bavel, 2006; Van Bavel, Moreels, Van de Putte, \& Matthijs, 2011), were more likely to adapt their fertility behaviour to new economic circumstances. They also tended to prioritise the quality 
of the children to match parents' material aspirations (Dribe et al., 2017; Pooley, 2013). The innovation perspective posited that the higher (and upwardly mobile) social strata were the first to adopt new social attitudes towards family planning as they were in a better position to acquire knowledge and information through education and wider social networks (Goldstein \& Klüsener, 2014; Klüsener et al., 2019; Szreter, 1996). They were also more apt to transform childbearing norms (Rogers, 1962). Thus, as Ansley Coale (1973) famously observed, a population needs to be 'ready, willing and able' to lower fertility, meaning that family size is reduced only when parents perceive it to be economically beneficial, limiting family size is ethically and culturally acceptable, and they possess the knowledge and means to control fertility (Dribe et al., 2017).

\section{The historical context of Tartu}

Tartu (also known as Dorpat or Jurjew at the time) was the second-largest town in Livland, one of the three Baltic provinces of the Czarist Empire. It was not a major industrial hub like Riga, the capital of Livland (and present-day Latvia) or Tallinn, the capital of Estland (and present-day Estonia). With regard to heavy industry there was only one factory, specialising in agricultural machinery, and a gas plant that mainly supplied the town. The other manufacturing enterprises were related to publishing or dealt with processing agricultural and timber products that were transported via railways from the surrounding region (Palamets, 2005, pp. 68-70). In total there were only about a thousand industrial workers in Tartu at the end of the nineteenth century. This means that the town preserved more of its merchantartisanal outlook than the burgeoning industrial centres. What set Tartu apart from the other towns in the Baltic provinces was its importance as an educational and cultural centre. This was due to the presence of a number of secondary schools as well as a university, a teachers' seminary, and the scientific and cultural societies that revolved around them (Berendsen and Maiste, 1999, pp. 166-172). 
Tartu, as well as the other areas of the Baltic provinces, had already achieved mass literacy by the time of the 1881 census, which is early by European standards (Kasekamp, 2010, p. 85; Raun, 1979). This was related to Lutheran teachings that prioritised the ability of individual believers to read scripture themselves. In Tartu there was also a considerable proportion of people with secondary or higher education, which was rare at the time. To be precise, $21 \%$ of the adult male and $12 \%$ of the adult female population had achieved a level of education higher than primary. The university, which was the major employer in Tartu (Leppik, 2006, p. 13), and other educational, medical and cultural institutions provided employment for these people. This means that Tartu had a relatively diverse occupational structure by the standards of the time.

The town was also ethnically heterogeneous. The Baltic Germans were the dominant force in the Baltic provinces in both the rural and urban areas. This population dates from the thirteenth century when Crusaders arrived at the eastern coast of the Baltic sea and conquered these lands for Christendom. This meant that in the Baltic provinces estate lines coincided with ethnic divisions. In Tartu, as in other towns, the Baltic Germans not only held political, economic and judicial power, but also constituted the majority. From the middle of the nineteenth century onwards, however, this situation changed rapidly due to urbanisation and the arrival of an Estonian peasant-origin populace, which was gradually emancipated from the dominion of the Baltic German nobility over the course of the century, as well as experiencing population increase due to the demographic transition. The population of Tartu thus doubled in a matter of a few decades. The permanent population at the time of the 1897 census was $40,636,71 \%$ of which were Estonians (46\% at the 1867 census), $17 \%$ Baltic Germans (42\% in 1867) with the remaining 12\% comprised mainly of Russians and Jews (Körber, 1902, pp. 40-43). The influence and number of Russians increased in the last decade of the nineteenth century with the Russification policies of the Czarist Empire, which 
curtailed the power of the Baltic Germans (Thaden, 1981; Haltzel, 1981). A permanent Jewish population was allowed to settle in Tartu as of the 1860s (Jokton, 1992, pp. 8-14).

Although the Baltic Germans had become a clear minority by the time, they still comprised most of the higher social class in Tartu and thus controlled the municipal council and government, as elections were based on property-defined suffrage (Raun, 2001, pp. 7374). A limited Estonian intellectual and entrepreneurial stratum had also emerged by the late nineteenth century, strengthened by the influx of motivated Estonians in search of opportunities for upward social mobility. The increase in their numbers enhanced their belief in the viability of the Estonian nation and led to the rejection of Germanisation, as they aimed to eliminate the prerogatives of the Baltic Germans (Jansen, 2007, pp. 376-386). This class became the backbone of the Estonian national movement and, due to its educational and cultural institutions, Tartu became its centre at the end of the century (Raun, 2001 p. 75). The vast majority of Estonians, however, were still employed in the low-wage sector, both traditional and contemporary.

Estonia was among the first countries to adopt modern fertility behaviour. The fertility transition in Estonia was already underway by the time of the first census in 1881. According to the available data sources, it appears that family limitation began with the cohorts of women born in the 1830 s and 1840 s - from the 1850 s and 1860s in period terms (Gortfelder \& Puur, 2019; Katus 1994). The fertility decline became more pronounced among the cohorts of women born in the $1870 \mathrm{~s}$ - in the $1890 \mathrm{~s}$ in period terms. It seems that Tartu and the other urban areas were among the forerunners of this development, which would situate our observation period at the end of the nineteenth century in the middle of the transition. However, the rural areas surrounding Tartu, from which the town drew most of its new inhabitants, were not at the forefront of family limitation. In Tartu County, fertility started to decline noticeably only from the 1890s onwards. 
Little is known about socio-economic differences in fertility during the demographic transition in Estonia in general or Tartu in particular. Based on the 1881 census of rural Estland, local statisticians provided information on fertility by dividing the populace into three groups (Jordan, 1884, pp. 132-133). These results revealed that fertility was highest amongst the elite (landowners, rural intellectuals), and that the lower classes (landless and semi-landless) had the least number of children. Unfortunately, similar information is not provided for Tartu or any other town in the region. Observations from the beginning of the twentieth century noted that amongst the upper and middle classes the two-child norm had taken root, and also that higher education was correlated with smaller families (Eisen, 1910; Köstner, 1915).

More is known about the mortality environment and socio-economic discrepancies in child mortality in Tartu (Jaadla \& Klesment, 2014; Jaadla, Puur, \& Rahu, 2017). Although child mortality had fallen during the second half of the nineteenth century the infant mortality rate for 1897-1900 was still 144 per 1000 live births (134 for legitimate births), although Tartu boasted a large number of medical facilities and personnel (Kalnin, 1980). The analysis also revealed noticeable differences in infant and child mortality according to the occupational group of the father, with the expected gradient. However, the greater survival chances for higher-status children were largely explained by differences in household-level sanitary conditions and access to water supply (Jaadla \& Puur, 2016).

\section{Data, method and measures}

\section{Data}

This article is based on a combination of two data sources, both preserved in the National Archives of Estonia. The first source is the individual records of the census conducted on 28 
January 1897. The census records are drawn from local copies of the census lists that were computerised during a research project in the 1990s (Berendsen \& Maiste, 1999). These provide information on the socio-economic and cultural characteristics of the individuals. The second set of data is comprised of the digitised birth and death registers of all the Lutheran parishes in Tartu for the years 1897-1899 (Jaadla, 2016). These yield information on the vital events occurring in the three years following the census. Because of the fragmentary preservation of parish registers for non-Lutheran congregations, we limit the study to Lutherans, who comprised the largest religious group in Tartu ( $84 \%$ of the total population in 1897).

$75 \%$ of the birth records were linked to their mothers in the census records. Linkage was most successful for the 1897 birth cohort (81\%) and least successful for that of 1899 (70\%). The linkage rate is similar to that reported in many linked-records studies of the period (Edvinsson, 1993, 1995; Hautaniemi, Anderton, \& Swedlund, 2000; Thornton \& Olson, 2011; Williams, 1992). Linking the two data sources was not always successful, likely due to continuing urbanisation in the years after the census. This in-migration does not present an issue for our analysis, as the study sample is based on couples enumerated during the census. Migration, of course, did not involve only in-migration. Some individuals registered as residents during the census also out-migrated. This does create a problem for our event history analysis, because we do not have a record of this migration event, meaning that some couples falsely remain in the risk set. The issue is especially significant for determining group differences, since out-migration was probably not homogeneous across sub-populations. In order to account for this issue, we compared the successfully linked birth records with all birth records. This revealed differences of no more than a few percentage points for the comparable characteristics, which were not statistically significant. We also ran alternative event history models, in which we shortened the observation period to 1897-1898. The results 
proved to be consistent. Thus, we do not consider out-migration to be an issue of enough importance to invalidate the main results.

\section{Method}

The analysis is conducted in two sections:

1) Cross-sectional approach:

a. Own-child method to estimate the level of fertility in the years preceding the census;

b. Linear regression on the census data to determine net fertility at the time of the census;

2) Discrete-time event history modelling of the linked census and register data to study the continuation of childbearing after the census.

We decided to use this combination of methods for three reasons. First, the design of the initial section confirms previous research that drew on census micro-data (Dribe et al., 2014; Dribe \& Scalone, 2014; Hacker, 2016; Klüsener et al., 2019) and thus enables a comparison with other settings. Second, the use of cross-sectional data has well-known limitations due to its anticipatory nature, meaning that past behaviour is determined based on variables recorded at the end of the period (Hoem \& Kreyenfeld, 2006). By adding an event history approach, we avoid these defects and complement the linear regression. Third, it reveals whether the results for group differences obtained from the event history approach could be invalidated by the problem of heterogeneous unregistered out-migration discussed above.

In the first section we use 'own children' below the age of five who are living with their mother at the time of the census. In order to estimate the level of fertility for Tartu we employ the own-child method first developed by Grabill and Cho (1965), whereby we use 
reverse-survival techniques to calculate age-specific and total fertility rates for the years preceding the census. The National Archives of Estonia has recently digitised the 1867 Tartu census, which allows us to also take a closer look at the changing fertility levels in the town in the second half of the nineteenth century. Our estimation procedure follows the work by Reid et al. (2019). Because the number of children without co-resident mothers increases considerably after age five, we limit own children to the younger ages, meaning that we observe the fertility rates for the five-year period preceding the year of the census. We calculate the total fertility rate for the town as well as distinguish Lutheran from other women. Adjustments to mortality for estimating the number of births by the age of the mother are based on single-year life tables (Jaadla et al., 2017). ${ }^{1}$

We also perform linear regression to analyse the effect of socio-economic status on fertility, in which the dependent variable is the number of own children below the age of five alive during the census. It is therefore an analysis of net marital fertility. This raises a question, whether in terms of gross fertility the picture would be different from net fertility. Scalone and Dribe (2012) tested this and concluded that the socio-economic gradient in fertility remained the same, when adjusting for early-life mortality. Our study sample is restricted to currently married Lutheran women aged 15 to 49 whose Lutheran husbands were present in the household at the time of the enumeration. This restriction is important because the socio-economic status of the family could only be defined by the husband's occupation. We exclude non-Lutherans from the linear regression model in order to bring it into conformity with the second section. This means that in this article we do not focus on the role of religious differences with regard to fertility.

\footnotetext{
${ }^{1}$ We make use of two life tables for the reverse-survival procedure: For the 1897 census we use a single-year life table that was previously estimated for the same population; for the 1867 census we use a life table for the year 1881. These are the earliest mortality estimates available for the town, and we are aware that they probably underestimate the level of mortality in 1867. However, previous assessments have demonstrated that the misspecification of mortality levels in the own-child method makes relatively little difference (Retherford \& Cho, 1978; Spoorenberg, 2014).
} 
In the second section, we use the linked-records data to perform a discrete-time event history analysis (Singer \& Willet, 2005) in order to examine the occurrence of a subsequent birth. Due to the differing logic of the model and data issues the study samples of the linear and event history models are not identical. In this set of models, we include only women who were mothers (i.e., had at least one surviving child) and younger than age 45 at the time of the census. In order to see the differences across parity progressions, we create four subsamples: i) all mothers; ii) mothers with one (surviving) child; iii) mothers with two (surviving) children; iv) mothers with three or more (surviving) children. Previous studies that have used event history methods have been based on continuous register data collected over decades or longer (Bengtsson \& Dribe, 2014; Breschi et al., 2014; Dribe et al., 2017; Molitoris \& Dribe, 2016; Van Bavel, 2004; Vézina et al., 2014). This is something we lack. We follow the design of the 2017 study by Van Landschoot et al., who used several years of linked census and postcensus register data to analyse contemporary Belgian fertility. Our analysis starts with the birth of the youngest child who was alive during the census. The census, unfortunately, did not record the date of birth, but only the age. For children over the age of one year this was given in full years, which is the main reason we use discrete rather than continuous time. The time lasts until the birth of the next child or one of the censoring events: i) death of the woman; ii) death of the husband; iii) the year 1900 . We remind the reader that we lack information on out-migration.

This means that although we start following the women from the year of birth of their last child, they are only considered to be at risk at the time of the census. This approach has two important consequences, as noted by Van Landschoot et al. (2017). First, the longer the interval between the year of birth of the last child and the date of the census, at which time the mother would enter our risk set, the higher the likelihood of left censoring. Left censoring happens when another child is born before the census date, so that the mother does not enter 
our risk set for the earlier parity transition. Second, women who died or whose husband died prior to the census are also excluded from our risk set. Our data are thus left-truncated as well. As we are dealing with an historical population, we should also note that child mortality might have occurred before the census and is hence unregistered in the data. The longer the pre-census period, the higher the likelihood of left-censoring due to the death of a child, and the higher the likelihood that the start of the observation is incorrect. In order to minimise these issues, we introduce a third restriction for the study sample compared with the linear regression. We limit our sample to women whose youngest living child at the time of the census had been born during the three years prior to the census. However, this six-year observation period has a disadvantage, since women with short birth intervals may predominate, and the scale may differ across sub-populations. We also ran models with a fiveyear restriction, and the results were in conformity.

\section{Measures}

The percentage distributions of the measures are presented in Table 1. The main variable of interest is the socio-economic status of the couple, which is based on the occupation of the husband. This is comprised of five major ISCO-88 occupational groups: elite and sales, professionals, skilled manual workers, service personnel and unskilled manual workers (ILO, 1990). The 'elite and sales' category includes capitalists, property and business owners, and managers (ISCO 1). By 'professionals' are meant those such as lecturers, teachers and officials, who are required to have a certain level of education for their occupation (ISCO 2-4). 'Skilled manual' are workers who have specific trades - carpenters, tailors, etc. (ISCO 6-8). Most 'service personnel' are servants (ISCO 5), and the majority of the 'unskilled manual' group are day-labourers (ISCO 9). As can be seen in Table 1, the preponderance of husbands is in the last two groups, and a small percentage have no occupational information. Based on the prevailing theory and previous empirical results 
outlined above, we would expect the elite and middle classes to have more motivation and opportunity to practice fertility limitation, especially in a university town, where information on modern views and customs would be disseminated more easily.

In Tartu, as elsewhere at the time, most women did not participate in market employment. Therefore, instead of distinguishing separate occupational groups for women, we use a binary variable indicating whether the woman was enumerated as employed or unemployed. However, this gives rise to an issue of reverse causality, since lack of employment may be the outcome of recent childbirth. Also, information regarding female labour market status is thought to have been faulty in many countries due to views of the gender division of labour (Dribe et al., 2014). Nevertheless, the information was included since its exclusion did not change the results for the other variables and it occupies an important place among the theoretical explanations for the fertility transition. It is noteworthy that almost half of the women in the Tartu labour market were in the unskilled manual category with the other half more or less evenly divided between the service personnel and skilled manual classifications. This indicates that female employment was associated with lower socio-economic status at that time, and would mean that at least in Tartu and the other urban areas we could expect a positive correlation between status and fertility (Molitoris \& Dribe, 2016).

We also include census information about education. In the main analysis, we use the level of education of the woman. Previous literature on family formation and fertility has highlighted the importance of women's education, as it empowers women financially and mentally, and thus breaks down traditional social and mental barriers (Becker, 1981; Sen, 1999; Basu, 2002; Cleland, 2002). Educational attainment has also been linked with decreased fertility in many recent studies (Becker, Cinnirella, \& Woessmann, 2010, 2013; Breierova \& Duflo, 2004). The education-fertility linkage is compatible with the economic and innovation- 
diffusion perspectives (Cleland, 2001) and thus could be interpreted as alternative variable for social status or as a cultural indicator that is associated with openness towards new behaviour and more independent thinking. Regardless of the approach, we would expect that in this midtransition period women with secondary education would have lower fertility.

As noted above, we are dealing with a fully literate population. The census does not provide information on the number of years of schooling, but registers the type of school the individual had attended. Since the school system included a plethora of primary and secondary educational facilities that were not strictly comparable (Berendsen and Maiste, p. 132) we use only a binary distinction between primary and secondary education. The costliness of secondary schooling at that time would support the socio-economic line of reasoning. However, the fact that most women with secondary education did not earn an income lends credence to the cultural argument.

In the Estonian context it is also important to note that for the majority Estonian population, it was impossible to acquire secondary education in their mother tongue, since in all of the secondary schools the language of instruction was either in German or Russian. People that attended secondary schools were thus fluent in German and/or Russian and more exposed to new ideas that were spreading at the time. Although, no comprehensive study on the diffusion of materials regarding family limitation in Estonia has been conducted, we can assume that this also applied to the topic of fertility restriction. The first known materials on the topic were published in Estonian only at the beginning of the $20^{\text {th }}$ century and these were translations from German and Russian. Also, other Estonian language literature that addressed marital relations and child-rearing were for the most part translations from German or Russian. Thus, we believe that secondary educated women, who were fluent in these languages, could have more knowledge on the topic of family limitation than elementary educated women. 
We also make use of a variable that indicates the migration status of the woman. There are several hypotheses regarding the connection between migration and fertility (Kulu, 2005). Unfortunately, the census of 1897 only provides the individual's place of birth, which means that we do not know when migration to Tartu occurred and are thus unable to test these hypotheses. We distinguish between women born in Tartu, Tartu County, other areas of (present day) Estonia, and abroad. Most of those born in Tartu County and other areas of Estonia are Estonians of peasant origin. The majority of those born abroad are non-Estonians with higher social status. By comparing the fertility behaviour of the migrant and permanent populations we gain insights into the socialisation and adaptation processes. Given that fertility in Tartu was significantly lower than in the surrounding areas and the Estonian countryside in general, the higher fertility of migrant women can be interpreted as evidence of the importance of early socialisation, and, therefore, of cultural factors in determining childbearing behaviour. The absence of fertility differences would attest to the relevance of adaptation to the mores of the area of residence, and thus to the significance of structural determinants of childbearing. Previous research has yielded mixed results for this dichotomy (Eggerickx, 2001; Oris, 1996; Schulz and Gruber 2018). A related topic concerns the importance of the distance of migration, which presumes that a longer distance was more likely to alter fertility behaviour, as it undermined existing social bonds more decisively (Klüsener et al. 2019). Our data would make it possible to test this hypothesis by comparing the results for Tartu County with other regions of Estonia.

The models incorporate other control variables such as the age of the woman, which in the event history approach is used as a time-dependent covariate. We also include the age difference between spouses. Due to the differing demands of the linear and event history models the control variables are not identical. Similarly, to previous studies our linear model makes use of the number of children aged five and above to control for differences in 
exposure or as a proxy for the length of the current marriage. The number of children at the time of the census is included in the event history models that do not deal with a particular net parity progression. In all of the event history models there is a time-varying indicator for child mortality. It is a binary variable that takes the value of 1 if any of the children enumerated at the census dies during the observation period. Finally, discrete-time analysis requires an inclusion of a categorical time variable that counts the passage of years from the last birth.

(Table 1 about here)

\section{Results}

Cross-sectional approach 


\section{Level of fertility in Tartu}

Table 2 shows the Total Marital Fertility Rates calculated for married women aged 20 to 49 $\left(\mathrm{TMFR}_{20}\right)$ in the five years preceding the censuses of 1867 and 1897. As expected, fertility in Tartu was higher in the earlier period; the $\mathrm{TMFR}_{20}$ fell from 6.04 in the 1860 s to 5.2 by the end of the century. The Lutheran population exhibits higher fertility than the total population, although the difference becomes negligible by the end of the nineteenth century. The results confirm that Tartu experienced a relatively early fertility transition in comparison with the rest of Europe. The other non-industrial university towns Oxford, Cambridge and Rostock for which there are comparable fertility estimates all had higher a $\mathrm{TMFR}_{20}$ at the turn of the century (6.9, 6.3 and 5.7 respectively) (Gruber \& Scholz, 2018; Reid et al., 2019). The capital and major industrial city Stockholm also had a fertility rate higher than Tartu (6) (Molitoris, 2015). Similarly, London's fertility was around 6 by 1901; however, the level varied by neighbourhood: The West End districts exhibited fertility levels as low as 5.2, whereas parts of the East End had TMFRs higher than 7 (Reid et al., 2019).

(Table 2 about here)

Table 3 gives descriptive results of the SES differences in fertility levels by presenting the number of children under the age of five per woman aged 20-49 at the time of the census in Tartu. The table indicates that women belonging to the elite and sales category did have a lower level of fertility compared to other social groups, as did women whose husbands worked as service personnel. Women married to professionals and skilled manual labourers, on the other hand had higher fertility. Those that were wed to unskilled labourers had a moderate fertility level.

(Table 3 about here) 


\section{Linear model}

Table 4 shows the results for the linear model. We remind the reader that the dependent variable is the number of living and present children aged $0-4$ and thus measures net (not gross) marital fertility. With regard to the socio-economic status of the husband clear differences are obvious across the five occupational groups. The elite and sales group has lower net fertility than most of the other groups, which indicates their pioneering role in the fertility transition and confirms theoretical expectations as well as earlier empirical research (Dribe et al., 2014; Dribe \& Scalone, 2014; Hacker, 2016; Klüsener et al., 2019). Some surprises, however, do emerge. Professionals have 0.15 more children under 5 than the elite and sales group, although one would expect the distinction to be low as there is little difference in material standards between the two groups. The other noteworthy result is the similarity of the estimates for the service personnel and the elite and sales groups. This might be explained by the fact that the majority of service personnel were engaged in domestic service. These individuals might also have had to postpone starting a family much longer than other social groups because of economic constraints. Skilled and unskilled manual labourers both have higher net fertility than the elite and sales group. The pattern that emerges with regard to the occupational status of the husband is therefore more complex than a simple negative linear correlation with net marital fertility.

The active labour market status of the woman has the expected negative influence on her number of young children, but we again caution the reader that this might be an incidence of reverse causal influence, i.e., being unemployed is for many women the outcome of having young children. The educational status and birthplace of the wife do not have a statistically significant effect on the dependent variable, which indicates that in Tartu at the time of the demographic transition, these factors determined fertility behaviour to a far lesser extent than material conditions. As the couples' borough of residence is known, we also ran models in 
which we added dummies for the 16 districts to control for the influence of the neighbourhood but this did not change our main results. This is not unusual, given that the boundaries between different social groups and neighbourhoods would not have been substantial in a comparatively small town. We also ran sensitivity tests in which we included the nonLutheran population of Tartu in order to increase heterogeneity; however, the education and birthplace of the wife still did not become significant. Although it becomes apparent that the Jewish population had 0.25 more children under age 5 than the Christian population in Tartu. This result is related The Jewish population in Tartu was new, since the restrictions regarding Jewish settlement were only loosened from the 1860 s onwards. Also, the majority of them arrived from Lithuanian and Polish territories, where the fertility transition started a few decades later than in Estonia (Coale \& Watkins, 1986).

(Table 4 about here)

\section{Event history approach}

The results of the event history models are presented in the four columns of Table 5. The first column on the left shows the results for all women who meet the conditions for inclusion in the event history analysis; the other three columns contain the results for models that deal with specific parity progressions (the last shows progressions from the third and higher parity to the next birth). Parity denotes net parity in the event-history models, since, as mentioned before, we cannot account for child mortality that occurred before the census. The dependent variable is the occurrence of another birth within six years of the birth of the last child. Before exploring the results in detail, we wish to make two general observations. First, a pattern emerges across the four models. There are a number of differences between groups in the model for all women and in the model that deals with the transition from the third or higher parity to next birth; however, there are no such differences for the transition from the 
first to the second child. This is meaningful given that at the time almost all women who had a first child also had a second. Group differences related to novel fertility behaviour (stopping) emerge for the decision whether or not to have a third, fourth or higher-order child. We will not highlight the lack of group differences for the transition from one to two children in the discussion of the results.

Second, from Table 5 it appears that there are a number of parameter estimates that are non-zero, but lack statistical significance according to conventional limits $(0.01,0.05,0.1)$. We remind the reader that due to restrictions imposed the sample sizes are rather small. With discrete-time event history analysis sample size is a common concern, since a number of dummy parameters have to be computed to represent the passage of time. We follow the advice of statisticians (Amrhein, Greenland, \& McShane, 2019; Hoem, 2008) who have remarked that omitting considerable parameter effects based on p-values is not wise. Here we interpret the effects that are considerable and relatively close to statistical significance as it is conventionally defined, if the findings conform to the theoretical expectations, previous research, and the results of our linear model.

The findings for our main variable of interest largely conform with those produced by the linear model. Couples in the elite and sales category have a lower likelihood of a subsequent birth compared with most of the other groups. Professionals were more likely to have another child compared with couples in the elite and sales category, although the results for professionals never reach statistical significance. With regard to the progression from a second to a third child and from a third and higher-order child to the next, professionals were approximately twice as likely as the reference category to continue childbearing. The other occupational group with a higher chance of a subsequent birth than the reference group is skilled manual labourers. This is clearly evident for the model that comprises all women (45\%) with regard to the transition from a third or higher-order child to the next (98\%). The 
estimate for the transition from the second to the third child is not significant for the skilled manual group, but given the high coefficient and other findings we can cautiously interpret the result as meaningful.

Couples in the service personnel category do not differ from the elite and sales group in their likelihood of having a subsequent birth, as in the linear model. However, the event history results for women married to unskilled manual labourers differ from the crosssectional results. The linear model indicates that such women have a higher net marital fertility than those who are married to men in the elite and sales group. The results presented in Table 5 show that the probability of a subsequent birth for the two categories do not differ according to the event history approach, with the exception of the model for the transition from the first to a second child, which suggests that unskilled manual labourers might have a lower rather than higher probability of transitioning to a subsequent birth. This is partly due to the fact that in the linear model childless women were also included in the study sample. If we eliminate them from the linear model the positive coefficient for unskilled manual labourers declines by a third.

The results for the other variables tend to conform with the results of the linear model. If the woman was recorded as being active in the labour market, she has a lower probability of progressing to another parity, although the estimate is only statistically significant for the progression from a third or higher order child to the next. Having a secondary education does not affect the likelihood of another birth, as it did not affect the level of net marital fertility.

The results of the wife's birthplace, however, do differ from those of the linear model. Women who were born in Tartu County have a much higher likelihood (81\%) of progressing from a third or higher order child to the next. There is also a higher likelihood for women born in other parts of Estonia, although statistical significance is achieved only in the model for all women. Given that the number of women born in other parts of Estonia is rather small 
and that it is theoretically expected that immigrants from rural areas have higher fertility, we believe that these results can be interpreted as meaningful. This is not the case for women born abroad, who in the model that includes all women seem to have a much lower probability of transitioning from a second to a third birth. We discussed the problem of unregistered out-migration in the data section and cautioned that the level of out-migration is not equal across groups. The theoretical expectation as well as additional inquiries indicate that those born abroad are the most mobile group. Thus, the results in Table 5 for this category are biased downward to the extent that makes the interpretation meaningless. The differences between the results of the linear and event history models are not resolved by the exclusion of childless women from the latter.

As with the linear model, we experimented with controlling for spatial heterogeneity in Tartu. This did not change the results for our main variables of interest. In the event history approach, it is also possible to control for the sex composition of the sibset, which have been shown to increase the probability of another birth (Reher et al., 2017). The creation of additional models that include these variables revealed the expected influence, although it did not reach the level of statistical significance in most cases.

(Table 5 about here)

\section{Discussion}

The aim of this study was to investigate the level of and socio-economic differences in fertility in Tartu, Estonia at the end of the nineteenth century. Our innovative approach was to perform analysis both using cross-sectional and event history analysis, whereas previous studies have tended to utilise one or the other. Both methods have obvious limitations (an 
anticipatory mode of observation in the cross-sectional approach, and unregistered outmigration in event history analysis); however, the fundamental conformity of our results is a clear indication that the patterns that emerge in fertility differences can be supported. First of all, our results corroborate findings indicating that fertility levels in Tartu were declining in the second half of the nineteenth century, and furthermore, that by the end of that century its estimated marital fertility was lower than that of structurally similar university towns in Western Europe, as well as major metropolitan cities like Stockholm and London. In addition, our results also demonstrate that there were considerable socio-economic differences in fertility in Tartu at the time, bearing in mind that it was a relatively small town, in which social stratification would not have been pronounced, and that this would favour similarity of behaviour.

We find that women married to men in the highest social group (elite and sales) exhibit a lower level of fertility than other groups, corroborating previous research in other settings (Bengtsson \& Dribe, 2014; Dribe et al., 2017; Molitoris \& Dribe, 2016). However, our results do not indicate that there was a linear relationship between socio-economic status and fertility. This is not surprising, given that the results of previous case studies have been quite heterogeneous in this regard (Dribe et al., 2017). This gives credence to the view of Szreter (1996) that social class, or social status and geography in a broader context, interacted in particular 'communication communities'. An interesting finding emerges in Tartu with regard to women married to professionals, i.e., the group comprised of teachers, lecturers, doctors, officials, etc. These women as well as those married to skilled manual labourers had the highest fertility in Tartu at that time, according to both the cross-sectional and event history approaches. This is remarkable, given that both from an adjustment and innovation perspective higher educated people are seen to be among the pioneers of fertility decline, since they are presumed to prefer quality over quantity of children, and to be well positioned 
to adopt innovative behaviour and to distance themselves from old customs and ideas. We are unable to provide a clear explanation of why this group might be an exception in Tartu. One Estonian social historian has argued that the intelligentsia in the Baltic Provinces resembled the nobility in their material circumstances and lifestyle to a greater degree than was characteristic of their peers in Western Europe (Leppik, 2006, p. 55). This enabled the wives of the intelligentsia to live a comfortable life in which domestic workers discharged the household tasks. The higher fertility of women married to skilled workers relative to those whose husbands were in the elite and unskilled worker categories is anticipated, since this has also been demonstrated in other contexts during the transition (Bengtsson \& Dribe, 2014; Dribe et al., 2017, 2014; Dribe \& Scalone, 2014).

The low fertility of the service personnel group is also noteworthy. There are two possible explanations. First, these couples were likely to be living in close proximity to members of the elite and sales group, and this close contact might have influenced their fertility preferences and family limitation practices. This would lend support to the innovation-diffusion explanation of the fertility decline. However, it should also be noted that a quarter of the women married to men in service also needed to earn a supplementary income, which would suggest an economic motivation. Economic constraints could also hinder early family formation among this group.

Unskilled manual workers are the only group for which the results of our two methodological approaches cannot be reconciled. There is no clear explanation why their higher net fertility established in the linear model does not translate into an increased probability of another birth in the event history model. Additional sensitivity tests do not indicate that women married to unskilled workers (along with their family) were more likely to out-migrate in the years following the census. A possible explanation for these results might involve longer birth intervals; this has been shown to be the case for day labourers in 
pre-transitional England (Cinnirella, Klemp, \& Weisdorf, 2017). In our case, the period of analysis is rather short and some of these births might not be captured in the event history approach. Finally, there is also the possibility that the fertility of unskilled workers was converging quickly towards that of the elite group at the time. And since the linear model measures fertility for the time before, and event history for the time after the census, this could be partly responsible for a statistically insignificant result for the latter.

We did not find any evidence that women's level of education affected fertility in latenineteenth-century Tartu. This is contrary to widespread evidence from non-Western contexts in the late twentieth and early twenty-first centuries, where sizeable educational differences existed with regard to fertility (Breierova \& Duflo, 2004; Cleland, 2001; Musa, 2002). How might this be explained? While there was relatively little variation in the level of education of the population, or in the measure of education that could be used in this analysis - the majority of those in our Tartu sample had the lowest level of schooling. Differences might have emerged in the number of years of schooling. However, as mentioned above, due to the complexity of the education system at the time we are unable to distinguish years of schooling. This means that our category 'primary educated' encompasses women with two to six years of schooling (Berendsen \& Maiste, p. 132) and thus obscures a wide variation. Nevertheless, it is surprising that women with secondary education do not differ from this broad group of women with primary education by the late nineteenth century, since attending institutions of secondary learning was a big step that was accessible to very few women at the time.

Regarding the connection between migration and fertility, we find in the event history models that at higher parity progressions, having been born outside of Tartu was associated with a higher probability of a subsequent birth, whereas women born in Tartu were more likely to exhibit earlier stopping behaviour. These results support our theoretical assumptions 
and previous empirical research (Gruber \& Scholz, 2018; Oris, 1996; Schumacher, Matthijs, \& Moreels, 2013) that found that rural migrants to urban areas adjust to the new surroundings by lowering their fertility, but not to the level of the native population.

There are a few limitations to this study that have been highlighted in earlier sections. First of all, unregistered out-migration in the three years following the census likely differs by particular sub-groups of the population and therefore does not allow us to properly evaluate the probability of a subsequent birth for women born abroad, or the possible differences in fertility between Estonians and Baltic Germans, given that there are sizeable differences in the groups' level of mobility. Second, we do not have full maternity histories for the women under study, which means that we are unaware of deceased children they had had before the census. With the linear model it affects the dependent variable, which raises the question if the results would be the same if we could measure gross instead of net fertility. We are unable to prove this with our data, although elsewhere it has been established that the gradient of socio-economic differences is unchanged (Scalone \& Dribe, 2012). With the event history model, the lack of full maternity histories affects our parity progressions, which are based on the number of children alive during the census and not the total number of births. Third, the availability of data from a single census year and a few years thereafter means that we are only able to obtain a snapshot of the population of Tartu during a process of fertility decline that evolved over decades. For this reason, our inferences concerning the socio-economic differences in fertility in Tartu do not reveal how they might have evolved over time, especially since research using data that encompassed decades has shown that there was considerable variation among socio-economic groups in terms of the tempo of the fertility decline (Molitoris \& Dribe, 2016). 


\section{References}

Amrhein, V., Greenland, S., \& McShane, B. (2019). Scientists rise up against statistical significance. Nature, 567(7748), 305-307.

Barnes, G. A., \& Guinnane, T. W. (2012). Social class and the fertility transition: a critical comment on the statistical results reported in Simon Szreter's "Fertility, class and gender in Britain, 1860-1940.” The Economic History Review, 65(4), 1267-1279.

Barnes, G. A., \& Guinnane, T. W. (2017). Rejoinder to Szreter. The Economic History Review, 70(3), 1004-1009.

Basu, A. M. (2002). Why does education lead to lower fertility? A critical review of some of the possibilities. World Development, 30(10), 1779-1790.

Becker, G.S. (1991). A treatise on the family. Cambridge, MA: Harvard University Press.

Becker, S. O., Cinnirella, F., \& Woessmann, L. (2010). The trade-off between fertility and education: evidence from before the demographic transition. Journal of Economic Growth, 15(3), 177-204.

Becker, S. O., Cinnirella, F., \& Woessmann, L. (2013). Does women's education affect fertility? Evidence from pre-demographic transition Prussia. European Review of Economic History, 17(1), 24-44.

Bengtsson, T., \& Dribe, M. (2014). The historical fertility transition at the micro level: Southern Sweden 1815-1939. Demographic Research, S14(17), 493-534.

Berendsen, V., \& Maiste, M. (1999). Esimene ülevenemaaline rahvaloendus Tartus: 28 Jaanuaril 1897. [The first Russian Imperial census in Tartu on $28^{\text {th }}$ of January 1897]. Tartu: Kirjastus Eesti Ajalooarhiiv. 
Breierova, L., \& Duflo, E. (2004). The Impact of Education on Fertility and Child Mortality: Do Fathers Really Matter Less Than Mothers? (Working Paper No. 10513). Retrieved from https://doi.org/10.3386/w10513

Breschi, M., Esposito, M., Mazzoni, S., \& Pozzi, L. (2014). Fertility transition and social stratification in the town of Alghero, Sardinia (1866-1935). Demographic Research, S14(28), 823-852.

Breschi, M., Fornasin, A., Manfredini, M., Mazzoni, S., \& Pozzi, L. (2011). Socioeconomic conditions, health and mortality from birth to adulthood, Alghero 1866-1925. Explorations in Economic History, 48(3), 366-375.

Brown, J. C., \& Guinnane, T. W. (2002). Fertility transition in a rural, Catholic population: Bavaria, 1880-1910. Population Studies, 56(1), 35-49.

Brown, J. C., \& Guinnane, T. W. (2007). Regions and time in the European fertility transition: problems in the Princeton Project's statistical methodology. The Economic History Review, 60(3), 574-595.

Carlsson, G. (1966). The decline of fertility: Innovation or adjustment process. Population Studies, 20(2), 149-174.

Casterline, J. B. (2001). Diffusion process and fertility transition: An introduction. In J. B. Casterline (Ed.) Diffusion processes and fertility transition (pp. 1-38). Oxford: Oxford University Press.

Cleland, J. (1985). Marital fertility decline in developing countries: theories and the evidence. In J. Cleand \& J. Hobcraft (Eds.) Reproductive change in developing countries (pp. 223-252). Oxford: Oxford University Press.

Cleland, J. (2001). Potatoes and pills: An overview of innovation-diffusion contributions to explanations of fertility decline. In J. B. Casterline (Ed.) Diffusion processes and fertility transition (pp. 39-65). Oxford: Oxford University Press. 
Cleland, J. (2002). Education and future fertility trends, with special reference to midtransitional countries. Completing the fertility transition (pp. 187-202). UN Population Division.

Cleland, J., \& Wilson, C. (1987). Demand Theories of the Fertility Transition: An Iconoclastic View. Population Studies, 41(1), 5-30.

Cinnirella, F., Klemp, M., \& Weisdorf, J., (2017). Malthus in the bedroom: birth spacing as birth control in pre-transition England', Demography, 54, 413-436.

Coale, A.J. (1973). The demographic transition reconsidered. In International Population Conference, Liège. 1973, vol. 1 (53-57). Liège: International Union for the Scientific Study of Population.

Coale, A.J. \& Watkins, S.C. (eds.) (1986). The decline of fertility in Europe. Princeton, NJ: Princeton University Press.

Coale, A.J., Anderson, B \& Härm, E. (1979). Human fertility in Russia since the nineteenth nentury Princeton, NJ: Princeton University Press.

Demeny, P. (1972). Early Fertility Decline in Austria-Hungary: a Lesson in Demographic Transition. In D.V. Glass and R. Revelle (Eds.) Reproductive change in developing countries (pp. 153-172). Oxford: Oxford University Press.

Davis, K. (1945). The World Demographic Transition. The Annals of the American Academy of Political and Social Science, 237, 1-11.

Dribe, M., Breschi, M., Gagnon, A., Gauvreau, D., Hanson, H. A., Maloney, T. N., Vézina, H. (2017). Socio-economic status and fertility decline: Insights from historical transitions in Europe and North America. Population Studies, 71(1), 3-21.

Dribe, M., Hacker, J. D., \& Scalone, F. (2014). The impact of socio-economic status on net fertility during the historical fertility decline: A comparative analysis of Canada, Iceland, Sweden, Norway, and the USA. Population Studies, 68(2), 135-149. 
Dribe, M., \& Scalone, F. (2014). Social class and net fertility before, during, and after the demographic transition: A micro-level analysis of Sweden 1880-1970. Demographic Research, 30, 429-464.

Easterlin, R.A. \& Crimmins E.M.. (1985). The fertility transition: A supply-demand analysis. Chicago, IL: Chicago University Press.

Edvinsson, S., Brändström, A., Rogers, J., \& Broström, G. (2005). High-risk families: The unequal distribution of infant mortality in nineteenth-century Sweden. Population Studies, 59(3), 321-337.

Eggerickx, T. (2001). The fertility decline in the industrial area of Charleroi during the second half of the 19th century: Did sedentaries and migrants have a different behaviour? Belgisch tijdschrift voor nieuwste geschiedenis/Revue belge d'histoire contemporaine, $31(3-4), 403-429$.

Eisen M. J. (1910). Eesti rahva kasvamine [The growth of the Estonian nation]. Eesti Kirjandus, 49-58.

Goldstein, J. R., \& Klüsener, S. (2014). Spatial Analysis of the Causes of Fertility Decline in Prussia. Population and Development Review, 40(3), 497-525.

Gortfelder, M., \& Puur, A. (2019). Demograafiline nüüdisajastumine Eestis: 1850-1899 sündinud naiste emaduslugude analüüs. Tuna: Ajaookultuuri ajakiri, 21(1), 19-38.

Grabill, W. H., \& Cho, L. J. (1965). Methodology for the Measurement of Current Fertility From Population Data on Young Children. Demography, 2, 50-73.

Guinnane, T. W., Okun, B. S., \& Trussell, J. (1994). What Do We Know About the Timing of Fertility Transitions in Europe? Demography, 31(1), 1-20.

Hacker, J. D. (2016). Ready, Willing, and Able? Impediments to the Onset of Marital Fertility Decline in the United States. Demography, 53(6), 1657-1692. 
Haines, M. R. (1995). Socio-economic Differentials in Infant and Child Mortality during Mortality Decline: England and Wales, 1890-1911. Population Studies, 49(2), 297315.

Haltzel, M. H. (1981). The Baltic Germans. Russification in the Baltic Provinces and Finland, 1855-1914. Princeton: Princeton University Press, 1981.

Hautaniemi, S. I., Anderton, D. L., \& Swedlund, A. (2000). Methods and Validity of a Panel Study Using Record Linkage: Matching Death Records to a Geographic Census Sample in Two Massachusetts Towns, 1850-1912. Historical Methods: A Journal of Quantitative and Interdisciplinary History, 33(1), 16-29.

Hoem, J. M. (2008). The reporting of statistical significance in scientific journals. Demographic Research, 18, 437-442.

Hoem, J. M., \& Kreyenfeld, M. (2006). Anticipatory analysis and its alternatives in lifecourse research: Part 1: Education and first childbearing. Demographic Research, 15, $461-484$.

International Labour Office (1990). International standard classification of occupations, ISCO-88. Geneva: International Labour Office.

Jaadla, H., \& Klesment, M. (2014). Infant mortality in the Lutheran population of Tartu at the end of the nineteenth century. Ajalooline Ajakiri. 2/3, 139-172.

Jaadla, H., \& Puur, A. (2016). The impact of water supply and sanitation on infant mortality: Individual-level evidence from Tartu, Estonia, 1897-1900. Population Studies, 70(2), 163-179.

Jaadla, H., Puur, A., \& Rahu, K. (2017). Socioeconomic and cultural differentials in mortality in a late 19th century urban setting: A linked records study from Tartu, Estonia, 18971900. Demographic Research, 36(1), 1-40. 
Jaadla, H., Reid, A., Garrett, E., Schürer, K, \& Day, J. (in press). Revisiting the fertility transition in England and Wales: The role of social class and migration. Demography.

Jansen, E. (2007). Eestlane muutuvas ajas: seisusühiskonnast kodanikuühiskonda [The Estonian in a changing time: From the estates society to civic society]. Tartu: Eesti Ajalooarhiiv.

Jokton, K. (1992). Juutide ajaloost Eestis [On the history of the Jews in Estonia]. Tartu: Tartu Ülikooli Kirjastus.

Jordan, P. (1884). Ergebnisse der ehstländischen Volkszählung: Die Zählung auf dem flachen Lande [The Results of the Census in Estland: The Census in the countryside]. Reval: Lindfors.

Kalnin, V. (1980). Tervishoid [Healthcare]. In: Pullat, R. (Ed.). Tartu ajalugu. Tallinn: Eesti Raamat, 149-153.

Kasekamp, A. (2010). A history of the Baltic Countries. Basingstoke: Palgrave Macmillan.

Klüsener, S., Dribe, M., \& Scalone, F. (2019). Spatial and Social Distance at the Onset of the Fertility Transition: Sweden, 1880-1900. Demography.

Kulu, H. (2005). Migration and Fertility: Competing Hypotheses Re-examined. European Journal of Population / Revue Européenne de Démographie, 21(1), 51-87.

Körber, B. (1902). Die stadt Dorpat (Jurjew) in statistischer und hygienischer beziehung [The statistical and hygienic overview of the town of Tartu]. Jurjew: C. Mattiesen.

Köstner, N. (1915) Rahva arvu kasvamine Eestimaal [The Growth of the Population in Estonia]. Tartu: Noor-Eesti.

Lee, R. D., Galloway, P. R., \& Hammel, E. A. (1994). Fertility Decline in Prussia: Estimating Influences on Supply, Demand, and Degree of Control. Demography, 31(2), 347. 
Leppik, L. (2006). Tartu Ülikooli teenistujate sotsiaalne mobiilsus 1802-1918 [The social mobility of the employees of the University of Tartu, 1802-1918] (Doctoral dissertation). Retrieved from https://dspace.ut.ee/handle/10062/842.

Liczbińska, G., Syska, E., Koziarska-Kasperczyk, R., \& Kledzik, A. (2018). Marital Fertility and the Family in Poland from the Late Nineteenth to the Early Twentieth Century. Journal of Interdisciplinary History, 49(2), 279-303.

Molitoris, J., \& Dribe, M. (2016). Ready to stop: socioeconomic status and the fertility transition in Stockholm, 1878-1926. The Economic History Review, 69(2), 679-704.

Notestein, F. (1945). Population - The long view. In T. W. Schultz (Ed.). Food for the World (pp. 36-57). Chicago, IL: University of Chicago Press.

Oris, M. (1996). Fertility and migration in the heart of the industrial revolution. The History of the Family, 1(2), 169-182.

Palamets, H. (2005). 19. sajand [19 ${ }^{\text {th }}$ century]. In H. Pullerits (Ed.). Tartu: Ajalugu ja kultuurilugu (pp. 65-72). Tartu: Ilmamaa.

Pakot, L., \& Öri, P. (2016). Socioeconomic and religious differentials in marital fertility during the fertility transition: A micro-level study from Western Hungary, 1850-1939. Demográfia English Edition, 58(5).

Pooley, S. (2013). Parenthood, child-rearing and fertility in England, 1850-1914. The History of the Family, 18(1), 83-106.

Raun, T. U. (1979). The development of Estonian literacy in the 18th and 19th centuries. Journal of Baltic Studies, 10(2), 115-126.

Raun, T. U. (2001). Estonia and the Estonians. Stanford, CA: Hoover Institution Press.

Reher, D. S. (1999). Back to the basics: mortality and fertility interactions during the demographic transition. Continuity and Change, 14(1), 9-31. 
Reher, D. S., Sandström, G., Sanz-Gimeno, A., \& van Poppel, F. W. A. (2017). Agency in Fertility Decisions in Western Europe During the Demographic Transition: A Comparative Perspective. Demography, 54(1), 3-22.

Reid, A. (1997). Locality or class? Spatial and social differentials in infant and child mortality in England and Wales, 1895-1911. In C. A. Corsini \& P. P. Viazzo (Eds.). The decline of infant and child mortality, the European experience: 1750-1990 (pp. 129-154) Hague: Martinus Nijhoff Publishers.

Reid, A. M., Arulanantham, S. J., Day, J. D., Garrett, E. M., Jaadla, H., Lucas-Smith, M. (2018). Populations Past: Atlas of Victorian and Edwardian Population. https://www.populationspast.org/. Accessed on [01.06.2019].

Reid, A., Jaadla, H., Garrett, E. \& Schürer, K. (2019). Adapting the 'own children method' to allow comparison of fertility between populations with different marriage regimes. Population Studies, 1-22.

Retherford, R. D., \& Cho, L.-J. (1978). Age-Parity-Specific Birth Rates and Birth Probabilities from Census or Survey Data on Own Children. Population Studies, $32(3), 567-581$.

Rogers, E. M. (1962). Diffusion of innovations. New York, NY: Free Press.

Scalone, F. and Dribe, M. (2012). Socioeconomic status and net fertility in the demographic transition: Sweden in 1900 - A preliminary analysis. Popolazione e Storia, 2, 111132.

Schumacher, R., Matthijs, K., \& Moreels, S. (2013). Migration and reproduction in an urbanizing context. Family life courses in 19th century Antwerp and Geneva. Revue Quetelet/Quetelet Journal, 1(1), 51-72.

Sen, A. (1997). Development as freedom. Oxford: Oxford University Press. 
Singer, J. D., \& Willet, J. B. (2005). Applied Longitudinal Data Analysis: Modeling Change and Event Occurrence. Journal of the American Statistical Association, 100(469), $352-353$.

Spoorenberg, T. (2014). Reverse survival method of fertility estimation: An evaluation. Demographic Research, 31, 217-246.

Szreter, S. (1996). Fertility, class and gender in Britain, 1860-1940. Cambridge, UK: Cambridge University Press.

Szreter, S. (2015). Fertility, social class, gender, and the professional model: statistical explanation and historical significance: Fertility, Social Class, and Gender. The Economic History Review, 68(2), 707-722.

Thaden, E. C. (1981). The Russian Government. Russification in the Baltic Provinces and Finland, 1855-1914. Princeton: Princeton University Press, 1981.

Thornton, P., \& Olson, S. (2011). Mortality in late nineteenth-century Montreal: Geographic pathways of contagion. Population Studies, 65(2), 157-181.

Van Bavel, J. (2004). Diffusion Effects in the European Fertility Transition: Historical Evidence from within a Belgian Town (1846-1910). European Journal of Population / Revue Européenne de Démographie, 20(1), 63-85.

Van Bavel, J. (2006). The Effect of Fertility Limitation on Intergenerational Social Mobility: The Quality-Quantity Trade-Off During the Demographic Transition. Journal of Biosocial Science, 38(04), 553.

Van Bavel, J., Moreels, S., Van de Putte, B., \& Matthijs, K. (2011). Family size and intergenerational social mobility during the fertility transition: Evidence of resource dilution from the city of Antwerp in nineteenth century Belgium. Demographic Research, S10(14), 313-344. 
Van Landschoot, L., de Valk, H., \& Van Bavel, J. (2017). Fertility among descendants of immigrants in Belgium: The role of the partner. Demographic Research, 36, 18271858.

Vézina, H., Gauvreau, D., \& Gagnon, A. (2014). Socioeconomic fertility differentials in a late transition setting: A micro-level analysis of the Saguenay region in Quebec. Demographic Research, 30, 1097-1128.

Wetherell, C., \& Plakans, A. (1997). Fertility and Culture in Eastern Europe: A Case Study of Riga, Latvia, 1867-1881. European Journal of Population / Revue Européenne de Démographie, 13(3), 243-268.

Williams, N. (1992). Death in its Season: Class, Environment and the Mortality of Infants in Nineteenth-century Sheffield. Social History of Medicine, 5(1), 71-94. 
Table 1. Percentage distributions of the variables used in the regression analysis

\begin{tabular}{|c|c|c|c|c|c|}
\hline & \multirow[t]{2}{*}{ Linear model } & \multicolumn{4}{|c|}{ Event history models } \\
\hline & & All mothers & $1 \rightarrow 2$ & $2 \rightarrow 3$ & $3+\rightarrow$ next \\
\hline \multicolumn{6}{|c|}{$N$ of children aged $>4$} \\
\hline 0 & 41.8 & & & & \\
\hline 1 & 23.5 & & & & \\
\hline 2 & 17.9 & & & & \\
\hline 3 & 9.7 & & & & \\
\hline 4 & 4.8 & & & & \\
\hline $5+$ & 2.3 & & & & \\
\hline \multicolumn{6}{|c|}{ Nof children } \\
\hline 1 & & 29.7 & & & \\
\hline 2 & & 29.1 & & & \\
\hline 3 & & 20.5 & & & 49.7 \\
\hline 4 & & 11.5 & & & 28.0 \\
\hline $5+$ & & 9.2 & & & 22.3 \\
\hline \multicolumn{6}{|c|}{ Years since last birth } \\
\hline 1 & & 3.8 & 5.3 & 4.1 & 2.5 \\
\hline 2 & & 14.0 & 19.3 & 12.3 & 11.4 \\
\hline $3-4$ & & 66.6 & 61.8 & 64.1 & 71.8 \\
\hline $5-6$ & & 15.6 & 13.6 & 19.5 & 14.3 \\
\hline \multicolumn{6}{|c|}{ Women experiencing child death(s) during observation } \\
\hline No & & 93.2 & 95.5 & 92.9 & 91.9 \\
\hline Yes & & 6.8 & 4.5 & 7.1 & 8.1 \\
\hline \multicolumn{6}{|c|}{ Woman's age } \\
\hline $15-29$ & 22.7 & 20.3 & 44.1 & 17.5 & 5.0 \\
\hline $30-34$ & 22.7 & 30.0 & 32.6 & 38.6 & 22.1 \\
\hline $35-39$ & 23.9 & 29.3 & 16.3 & 28.0 & 39.7 \\
\hline $40+$ & 30.6 & 20.4 & 7.0 & 15.9 & 33.2 \\
\hline
\end{tabular}


Wife older

Husband older 0-5 years

Husband older 6+ years

Husband's social class

Elite and sales

Professional

Skilled manual

Service personnel

Unskilled manual

Unknown

Woman employed

No

Yes

\section{Woman's education}

Primary

Secondary

Unknown

Woman's birthplace

Tartu

Tartu County

Estonia

Abroad

\section{1}

39.8

43.1

14.9

5.0

32.5

9.5

35.1

3.0

80.7

19.3

91.3

7.1

1.6

12.2

62.3

18.8

6.7
17.5

43.9

38.6

13.5

5.3

35.4

7.6

35.8

2.5

84.9

15.1

92.7

6.2

1.1

13.6

16.6

12.1

12.6

61.5

59.4

61.6

62.8

18.6

18.2

20.5

17.6

6.3

5.9

5.8

7.0

Spells ending with a birth
14.7

41.6

12.4

5.2

36.8

5.2

38.1

16.2
54.1

45.9
44.9

55.1
55.9

44.1

Yes

3,718

1,256

374

365

517

Note: The values of the time-dependent variables are presented at the end of the episode.

Sources: Lutheran parish registers and the 1897 census; source materials are preserved in the National Archives of Estonia, Tartu, Estonia. 
Table 2. Total marital fertility rates $\left(\mathrm{TMFR}_{20}\right)$ for married women aged 20 to 49 1862-1867 and 1892-1897, Tartu

\section{2-1867 1892-1897}

\begin{tabular}{lcc}
\hline Tartu (overall) & 6.04 & 5.20 \\
Lutheran population & 6.91 & 5.23
\end{tabular}

Sources: Lutheran parish registers and the 1867 and 1897 censuses; source materials are preserved in the National Archives of Estonia. 
Table 3. Child-woman ratios $\left(\mathrm{CWR}_{20}\right)$ at the time of the census for married Lutheran women aged 20 to 49 for years 1892-1897, Tartu

\begin{tabular}{lc}
\hline & CWR $_{20}$ \\
\hline Elite and sales & 0.564 \\
Professionals & 0.714 \\
Skilled manual & 0.689 \\
Service personnel & 0.556 \\
Unskilled manual & 0.636 \\
\hline
\end{tabular}

Sources: Same as for Table 1. 
Table 4. Linear regression of net marital fertility

\begin{tabular}{|c|c|c|}
\hline & coef & $\mathbf{p}$ \\
\hline \multicolumn{3}{|l|}{ Husband's social } \\
\hline Elite and sales & Ref. & \\
\hline Professional & 0.15 & 0.022 \\
\hline Skilled manual & 0.13 & 0.001 \\
\hline Service personnel & 0.03 & 0.607 \\
\hline Unskilled manual & 0.13 & 0.001 \\
\hline \multicolumn{3}{|l|}{ Woman employed } \\
\hline No & Ref. & \\
\hline Yes & -0.14 & 0.000 \\
\hline \multicolumn{3}{|c|}{ Woman's education } \\
\hline Primary & Ref. & \\
\hline Secondary & -0.03 & 0.536 \\
\hline \multicolumn{3}{|c|}{ Woman's birthplace } \\
\hline Tartu & Ref. & \\
\hline Tartu County & -0.03 & 0.396 \\
\hline Estonia & -0.05 & 0.283 \\
\hline Abroad & -0.04 & 0.508 \\
\hline R squared & 0.13 & 0.000 \\
\hline N of women & 3,718 & \\
\hline
\end{tabular}

Notes: Models control for the number of children aged 5+, the age of the woman, and the age difference between spouses. Some covariates had a separate category for unknown values; the estimates for this category are not reported.

Sources: Same as for Table 1. 
Table 5. Discrete-time event history models for the probability of another birth

\begin{tabular}{|c|c|c|c|c|c|c|c|c|}
\hline & \multicolumn{8}{|c|}{ Net parity progressions } \\
\hline & \multicolumn{2}{|c|}{ All progressions } & \multicolumn{2}{|c|}{$1 \rightarrow 2$} & \multicolumn{2}{|c|}{$2 \rightarrow 3$} & \multicolumn{2}{|c|}{$3+\rightarrow$ next } \\
\hline & coef & $p$ & coef & $p$ & coef & $p$ & coef & $p$ \\
\hline \multicolumn{9}{|c|}{ Husband's social class } \\
\hline Elite and sales & 1 & & 1 & & 1 & & 1 & \\
\hline Professional & 1.43 & 0.184 & 0.79 & 0.622 & 2.23 & 0.150 & 1.90 & 0.167 \\
\hline Skilled manual & 1.46 & 0.014 & 1.11 & 0.698 & 1.44 & 0.185 & 1.98 & 0.016 \\
\hline Service personnel & 1.25 & 0.290 & 1.13 & 0.707 & 1.22 & 0.628 & 0.97 & 0.954 \\
\hline Unskilled manual & 0.91 & 0.569 & 0.71 & 0.204 & 0.85 & 0.556 & 1.31 & 0.354 \\
\hline \multicolumn{9}{|l|}{ Woman employed } \\
\hline No & 1 & & 1 & & 1 & & 1 & \\
\hline Yes & 0.80 & 0.115 & 1.00 & 0.998 & 0.65 & 0.129 & 0.67 & 0.083 \\
\hline \multicolumn{9}{|c|}{ Woman's education } \\
\hline Primary & 1 & & 1 & & 1 & & 1 & \\
\hline Secondary & 0.87 & 0.574 & 0.86 & 0.757 & 0.69 & 0.472 & 0.99 & 0.983 \\
\hline \multicolumn{9}{|c|}{ Woman's birthplace } \\
\hline Tartu & 1 & & 1 & & 1 & & 1 & \\
\hline Tartu County & 1.17 & 0.281 & 0.85 & 0.488 & 1.24 & 0.499 & 1.83 & 0.027 \\
\hline Estonia & 1.34 & 0.082 & 1.25 & 0.411 & 1.58 & 0.182 & 1.45 & 0.234 \\
\hline Abroad & 0.69 & 0.143 & 0.86 & 0.706 & 0.47 & 0.175 & 0.77 & 0.549 \\
\hline $\mathrm{N}$ of women & 1,255 & & 373 & & 365 & & 517 & \\
\hline
\end{tabular}

Notes: Models control for the age of the woman, the age difference between the spouses, and the number of children, without reference to a specific parity transition. The coefficients are exponentiated. Some covariates contain a separate category for unknown values; however, the estimates for this category are not reported.

Sources: Same as for Table 1. 